\title{
Role of Antenatal Intervention and Pregnancy Outcome in Large Chorioangiomas
}

\author{
Bindiya Dhingra ${ }^{1} \cdot$ Adinarayan Makam $^{1}$
}

Received: 3 January 2020/Accepted: 27 February 2020/Published online: 23 March 2020

(C) The Author(s) 2020

\begin{abstract}
Chorioangioma is a non-trophoblastic benign vascular tumour of the placenta affecting fetal outcome. It has no malignant potential. It is usually diagnosed during the 2 nd trimester. These are usually found on the fetal side of the placenta, close to the umbilical cord insertion site protruding into the amniotic cavity. Chorioangiomas can be small or large. Small tumours (less than $5 \mathrm{~cm}$ ) usually have favourable outcome. Large chorioangiomas (more than $5 \mathrm{~cm}$ ) usually have an unfavourable outcome and may cause maternal complications like pre-eclampsia, preterm labour, placental abruption, placenta previa, polyhydramnios and post partum haemorrhage and fetal complications like anemia, thrombocytopenia, growth restriction, hydrops, cardiomegaly, congestive heart failure and intrauterine fetal demise. With the use of ultrasound and color Doppler, it has become possible to diagnose these early and provide timely intervention in order to prevent fatal complications. Here, we present a case of a large chorioangioma, $10 \times 8.7 \times 9.3 \mathrm{~cm}$, with significant high vascularity and fetal anemia. There was a significant reduction in the size of tumour after interstitial laser coagulation. Following this, an intrauterine transfusion helped in correcting anemia. Other intervention options available for chorioangiomas are endoscopic surgical devascularization, alcoholic ablation and radiofrequency ablation. Polyhydramnios if present, is treated with therapeutic amniocentesis. Delivery is to be considered in case of complications after 34 weeks of gestation. Small
\end{abstract}

Bindiya Dhingra

bindiyadhingra237@gmail.com

1 ADI Advanced Centre for Fetal Care, Sparsh Hospital, Yeshwanthpur, Bangalore, India chorioangiomas are usually favourable and require close fetal monitoring only.

Keywords Chorioangioma - Non trophoblastic $\cdot$ Benign · Anemia $\cdot$ Intervention

\section{Introduction}

Chorioangioma is the most common benign vascular tumour of the placenta [1] and is one of the rare causes of poor fetal outcome. It is a non-trophoblastic disease seen in approximately $0.5-1 \%$ of pregnancies [2]. It is usually diagnosed during the 2 nd trimester and is more common in multiple pregnancies and in the female fetus. These are usually seen on the fetal side of the placenta [3]. Chorioangiomas can be small or large. Small tumours (less than $5 \mathrm{~cm}$ ) are usually asymptomatic and have a favourable outcome [4]. Large chorioangiomas (more than $5 \mathrm{~cm}$ ) usually have an unfavourable outcome and result in maternal and fetal complications [5].

We present a rare case of a large chorioangioma which was completely devascularised after antenatal intervention.

\section{Case Report}

A 30 year old, Gravida 2, Para 1, Living 1 was referred at 25 weeks of gestation for a second opinion for chorioangioma of the placenta. There was a significant history of intermittent pain in the abdomen for 20 days. There was no other significant medical or surgical history. No gross fetal structural abnormalities were noted. A normal AFI of $19 \mathrm{~cm}$ was observed. The placenta was posterior. 
On ultrasound examination, a well defined hypoechoic mass of size $8.8 \times 7.5 \times 7.3 \mathrm{~cm}$ was seen distinctly separate from normal surrounding anterior placental tissue, bulging on the fetal side. Color Doppler showed significant high vascularity in the mass with a large central feeding vessel.

On spectral Doppler, low resistance flow was noted. MCA PSV was increased to $56 \mathrm{~cm} / \mathrm{s}(1.77 \mathrm{MoM})$ suggestive of a hyperdynamic circulation and/or severe fetal anemia. It was also associated with mild global cardiomegaly and mild pericardial effusion. Fetal Heart Quotient (Fetal HQ) was done and was found to be abnormal. The patient was counselled to undergo antenatal intervention. Various options were offered to the couple which included radiofrequency ablation, interstitial laser and/or intrauterine blood transfusion. Inspite of extensive counseling the couple refused to undergo any procedure at the first visit.

The couple visited again after a week. The size of the chorioangioma had increased to $10 \times 8.7 \times 9.3 \mathrm{~cm}$ with significant high vascularity (Figs. 1, 2 and 3). MCA PSV was increased to $62 \mathrm{~cm} / \mathrm{s}(1.8 \mathrm{MoM})$ and HQ had worsened. The couple decided to undergo treatment for chorioangioma first followed by intrauterine transfusion later if required.

Cordocentesis followed by insterstitial laser treatment was done. On cordocentesis, $\mathrm{Hb}$ was found to be $9 \mathrm{gm} \%$ which did not require transfusion. Laser therapy was done using a $17 \mathrm{G}$ needle with laser energy of $10 \mathrm{~W}$ for 3 cycles to ablate large feeding vessels within the tumour. Complete cessation of flow was noted in the chorioangioma. The fetus tolerated the procedure well and Fetal Heart Rate was $150 \mathrm{bpm}$. No evidence of amnion chorion separation or bleeding was noted.

The patient was asked to follow up post procedure. After 1 week at 27 weeks of gestation, the size of chorioangioma had reduced to $8.1 \times 6.5 \times 5.1 \mathrm{~cm}$ and MCA PSV had increased to $84.6 \mathrm{~cm} / \mathrm{s}(2.5 \mathrm{MoM})$. HQ had significantly worsened and a decision of intrauterine blood transfusion was taken. Pre transfusion $\mathrm{Hb}$ was $4.3 \mathrm{~g} / \mathrm{dl} .100 \mathrm{ml}$ of ' $\mathrm{O}$ ' $\mathrm{Rh}$ negative packed cells, irradiated, leucoinfiltrated, cross matched against mother's blood group was transfused under continuous ultrasound guidance. $20 \mathrm{~min}$ post transfusion, MCA PSV was $60 \mathrm{~cm} / \mathrm{s}$ with a Fetal Heart Rate of $134 \mathrm{bpm}$. Post transfusion $\mathrm{Hb}$ was $9.3 \mathrm{~g} / \mathrm{dl}$.

The patient was asked to follow up after 2 weeks at 29 weeks of gestation. The chorioangioma had reduced to $5.8 \times 3.5 \times 2.4 \mathrm{~cm}$ and MCA PSV was $70 \mathrm{~cm} / \mathrm{s}(1.7$ $\mathrm{MoM}$ ) with still worsened HQ. An intrauterine transfusion was repeated again because the $\mathrm{Hb}$ was $6.8 \mathrm{gm} / \mathrm{dl} .20 \mathrm{~min}$ post transfusion, MCA PSV was $58 \mathrm{~cm} / \mathrm{s}$ with a Fetal Heart Rate of $140 \mathrm{bpm}$ and Post transfusion $\mathrm{Hb}$ was $12 \mathrm{gm} \%$.

The patient was asked to follow up 2 weeks after the transfusion. The chorioangioma was completely devascularised. Cardiomegaly and pericardial effusion had
Fig. 1 Giant chorioangioma of the placenta

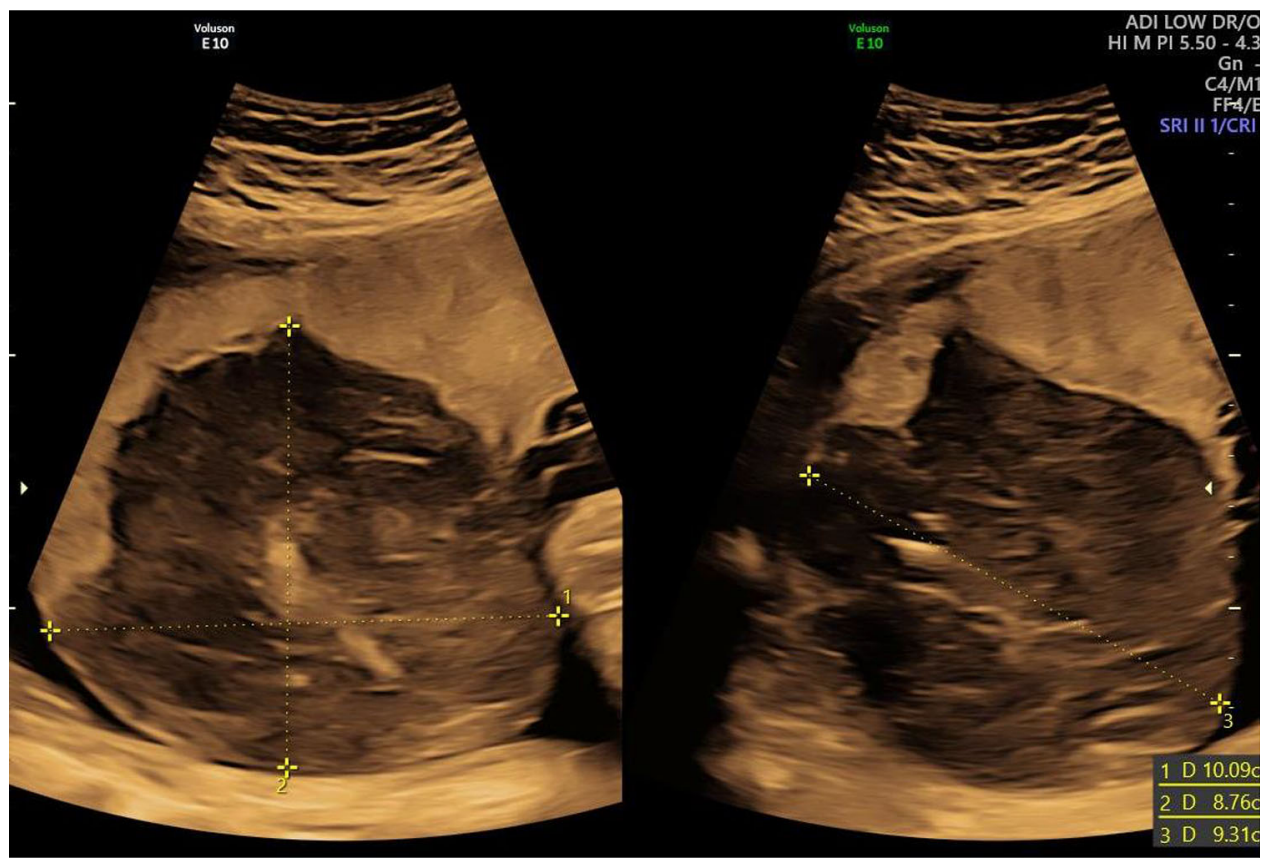


Fig. 2 Grey scale and power Doppler showing large central feeding vessel in the mass

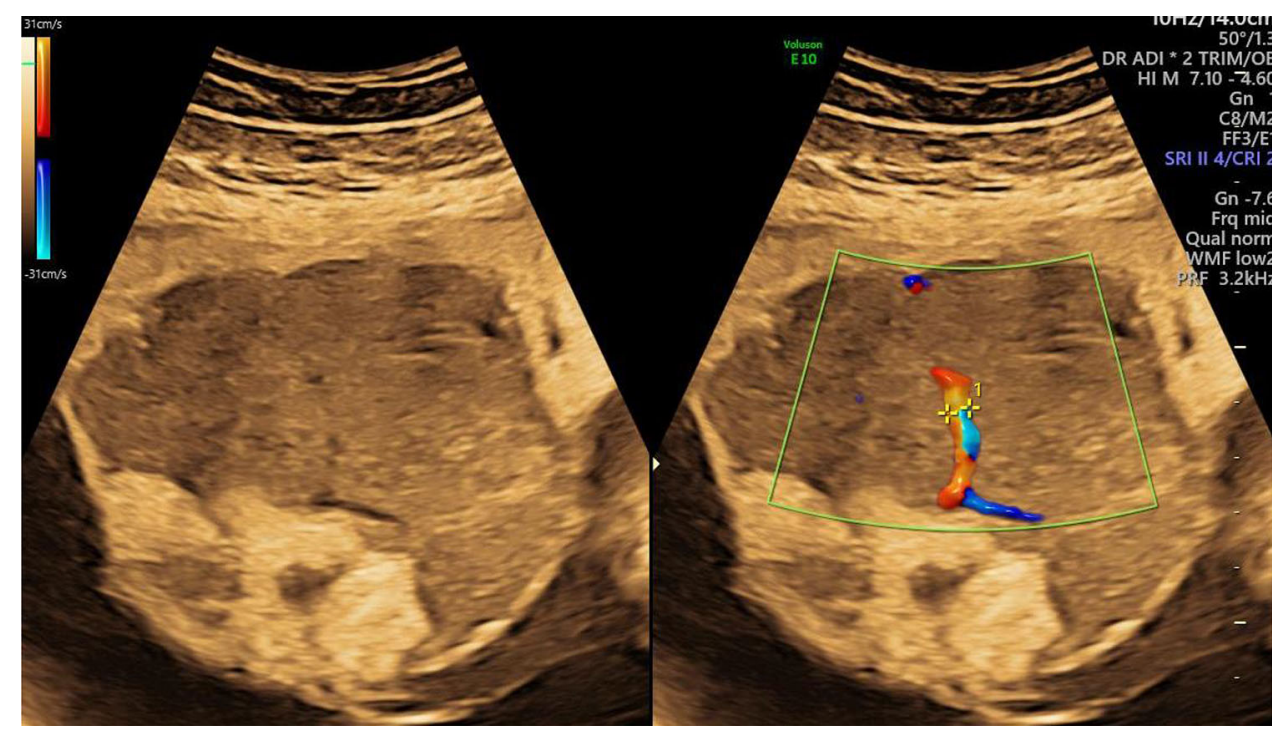

Fig. 3 Power Doppler of the placental chorioangioma showing vascularity of the mass

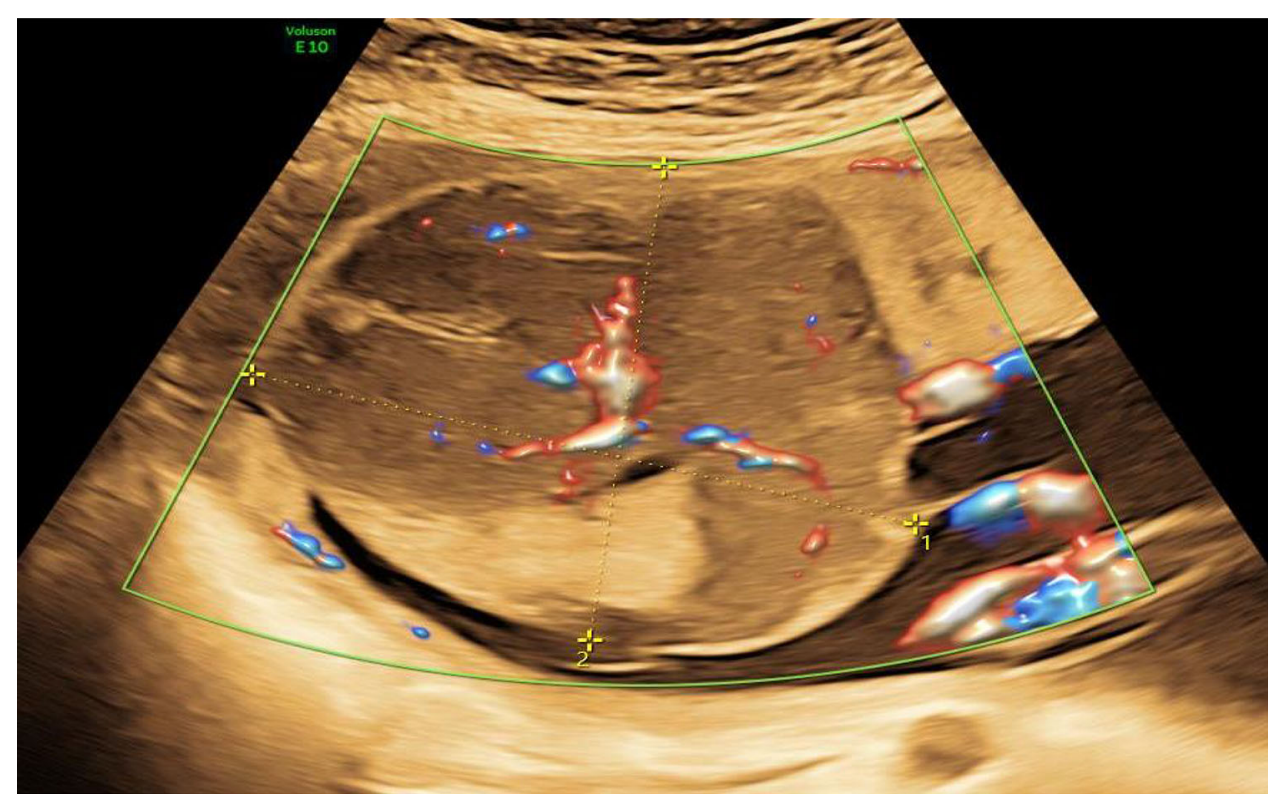

resolved. There was no tricuspid regurgitation. MCA PSV was $54 \mathrm{~cm} / \mathrm{s}$ (1.35 MoM) which was normal for that gestational age and ductus venosus was also found normal. Fetal echo and fetal HQ were also found normal.

The patient was asked to follow up every 2-3 weeks till term and was delivered vaginally at 38 weeks following spontaneous rupture of membranes. A healthy baby weighing $3 \mathrm{~kg}$ was born with Apgar score of 8 and 9 after 1 and 5 min respectively. The placenta was delivered completely and was sent for histopathological examination. Cord blood was sent for investigating neonate's $\mathrm{Hb}$ immediately after birth which showed a $\mathrm{Hb}$ of $16 \mathrm{gm} \%$. No blood transfusion was required and the neonatal period was uneventful.

\section{Discussion}

Placental chorioangioma is the most common benign tumour of the placenta with no malignant potential [1]. It is believed to be arising from the chorionic tissue due to abnormal proliferation of vessels by the 16th day of fertilization; however, there is no documentation of such cases in the 1st trimester [6]. These are usually found on the fetal side of the placenta, close to umbilical cord insertion site protruding into the amniotic cavity [7]. These are more commonly seen in elderly primigravidae, multiple pregnancy, hypertension and diabetes [7].

Macroscopically, they are well circumscribed, purplish red tumours with soft and dark, red to tan cut surface. 
Microscopically, there are 3 histological patterns as described by Marchetti [8]; angiomatous, cellular and degenerate, out of which angiomatous type is the most common. The angiomatous type is composed of numerous proliferative blood vessels, capillaries and small areas of endothelial tissue surrounded by placental stroma.

Small chorioangiomas of diameter less than $5 \mathrm{~cm}$ are usually asymptomatic and unlikely to cause any complications. Large tumours probably act as arteriovenous (AV) shunts and cause various maternal and fetal complications [9]. Maternal complications include pre-eclampsia, preterm labour, placental abruption, placenta previa, polyhydramnios and post partum haemorrhage. Fetal complications include anemia, thrombocytopenia, growth restriction, hydrops, cardiomegaly, congestive heart failure and intrauterine fetal demise [10]. These AV shunts impair fetal circulation by increasing venous return to the heart resulting in the possibility of high output cardiac failure, edema, non immune fetal hydrops, fetal growth restriction and intrauterine fetal demise [9].

With the advent use of ultrasound, early diagnosis and close fetal monitoring for such cases has become possible. 2D imaging generally shows a well circumscribed, complex or hypoechoic round mass, separated from the rest of the placenta, located near the umbilical cord insertion site and protruding into the amniotic cavity [7]. Color Doppler demonstrates increased flow with a low resistance pulsatile flow within the hypoechoic area [11] and is the gold standard in differentiating chorioangioma from its other differential diagnoses such as teratoma, placental haemorrhage, degenerating myomas, partial hydatiform mole and chorioangiocarcinoma [12, 13].

This case presented with a large chorioangioma with high vascularity and severe fetal anemia. Large chorioangiomas are associated with high perinatal morbidity and mortality [9, 14]. Chorioangiomas with complications before fetal viability requires interventions. There was successful outcome with insterstitial laser coagulation followed by intrauterine blood transfusions. Other treatment modalities include endoscopic surgical devascularization, alcoholic ablation and radiofrequency ablation [15]. Polyhydramnios if present, is treated with therapeutic amniocentesis. The administration of steroids is indicated to accelerate fetal lung maturity before 34 weeks. Delivery is to be considered in case of complications emerging after 34 weeks of gestation [9].

In our case, we chose laser coagulation over radiofrequency ablation so that cordocentesis could be done with a single needle used for laser coagulation to find out $\mathrm{Hb}$ level and to rule out fetal anemia as well.

Small chorioangiomas usually have a favourable outcome and require close fetal surveillance only [4].

\section{Conclusion}

Chorioangiomas have potentially serious adverse effects on pregnancy outcome. A large chorioangioma is a risk factor for various maternal and fetal complications. Timely diagnosis, close and regular fetal monitoring by ultrasound and Doppler velocimetry for early recognition and prevention of adverse events with timely intervention yields an optimal outcome.

\section{Compliance with ethical standards}

Conflict of interest The authors declare that they have no conflict of interest.

Open Access This article is licensed under a Creative Commons Attribution 4.0 International License, which permits use, sharing, adaptation, distribution and reproduction in any medium or format, as long as you give appropriate credit to the original author(s) and the source, provide a link to the Creative Commons licence, and indicate if changes were made. The images or other third party material in this article are included in the article's Creative Commons licence, unless indicated otherwise in a credit line to the material. If material is not included in the article's Creative Commons licence and your intended use is not permitted by statutory regulation or exceeds the permitted use, you will need to obtain permission directly from the copyright holder. To view a copy of this licence, visit http://creativecommons. org/licenses/by/4.0/.

\section{References}

1. Akercan F, Oncul Seyfettinoglu S, Zeybek B, Cirpan T. Highoutput cardiac failure in a fetus with thanatophoric dysplasia associated with large placental chorioangioma: case report. J Clin Ultrasound. 2012;40(4):231-3.

2. Sethi SK, Hemal U, Solanki RS, Bhagra A. Chorioangioma of placenta: a case report. Indian J Radiol Imaging. 2004;14:65-6.

3. Kesrouani AK, Safi J, El Hajj MA. Rapid evolution of placental chorioangioma: natural progression and outcome. JUM. 2013;32(3):545-8.

4. Hirata GI, Masaki DI, O’Toole M, Medearis AL, Platt LD. Color flow mapping and Doppler velocimetry in the diagnosis and management of a placental chorioangioma associated with nonimmune fetal hydrops. Obstet Gynecol. 1993;81((5(Pt 2)):850-2.

5. Duro EA, Moussou I. Placental chorioangioma as the cause of non-immunologic hydrops fetalis; a case report. Iran J Pediatr. 2011;21(1):113-5.

6. Bracero LA, Davidian M, Cassidy S. Chorioangioma: diffuse angiomatous form. 1993-09-18-11 Chorioangioma: diffuse angiomatous form Bracero. http://www.thefetus.net/.

7. Guschmann M, Henrich W, Entezami M, Dudenhausen JW. Chorangioma-new insights into a well-known problem. I. Results of a clinical and morphological study of 136 cases. J Perinat Med. 2003;31:163-9.

8. Marchetti A. A consideration of certain types of benign tumors of the placenta. Surg Gynecol Obstet. 1939;68:733-43.

9. Kodandapani S, Shreshta A, Ramkumar V, Rao L. Chorioangioma of placenta: a rare placental cause for adverse fetal outcome. Case Rep Obstet Gynecol. 2012;2012:913878. 
10. Mahajan R, et al. Chorioangioma with fetal anemia and polyhydramnios: a case report. Int J Reprod Contracept Obstet Gynecol. 2017;6(1):351-4.

11. Bashiri A, Furman B, Erez O, Wiznitzer A, Holcberg G, Mazor $\mathrm{M}$, et al. Twelve cases of placental chorioangioma. Pregnancy outcome and clinical significance. Arch Gynecol Obstet. 2002;266(1):53-5.

12. Jauniaux E, Campbell S. Ultrasonographic assessment of placental abnormalities. Am J Obstet Gynecol. 1990;163(5 Pt 1):1650-8.

13. Harris RD, Barth RA. Sonography of the gravid uterus and placenta: current concepts. AJR Am J Roentgenol. 1993;160(3):455-65.
14. Barros A, Freitas AC, Cabral AJ, Camacho MC, Costa E, Leitao $\mathrm{H}$, et al. Giant placental chorioangioma: a rare cause of fetal hydrops. BMJ Case Rep. 2011;02:3880.

15. Haak MC, Oosterhof H, Mouw R. Pathophysiology and treatment of fetal anemia due to placental chorangioma. Ultrasound Obstet Gynecol. 1999;14:68-70.

Publisher's Note Springer Nature remains neutral with regard to jurisdictional claims in published maps and institutional affiliations. 